\title{
Economics 10x10 - Lessons from the Last Ten Decades of Hungarian Economic History
}

Summary

This paper overviews the economic history of Hungary in the last 100 years, and especially the convergence process to the advanced economies which was hindered by severe external shocks, two world wars, global economic crises and the suppression by the Soviet Union. After the political transition of 1990, many expected a rapid economic miracle, but the economic transition period was prolonged for 20 years. Thus, the sustainable convergence has started only after 2010 when the necessary fiscal, monetary and structural reforms were implemented. The most important lesson we can draw from our economic history is that economic growth cannot be sustained without financial balance, thus economic policy has to find the effective and targeted measures to enhance economic growth and macrofinancial balance at the same time.

Journal of Economic Literature (JEL) codes: N14, E60, H11

Keywords: economic history, economic cycles, public policy

\section{INTRODUCTION}

Despite substantial research effort of excellent economists (from Smith, 1959 to Acemoglu and Robinson, 2012) it is still debated what are the causes of rise and fall of nations. One useful mean at hand to deepen our understanding about the key drivers is offered by economic history. Looking at long time periods we can identify repeating

Barnabás Virág, Deputy Governor of Magyar Nemzeti Bank responsible for monetary policy and financial stability. 
Civic Review · Vol. 16, Special Issue, 2020

patterns or economic cycles which can help to understand how developments at the global level influenced the fortune of nations.

The approach offered by economic history helps to explain the continuous struggle of Hungary to catch up with the living standards of developed European countries. During Hungary's long history geopolitics has always played an important role. With the exception of the 14th and 15th centuries, Hungary rarely experienced continuous and independent development and several times suffered severe shocks. The past 100 years were hard as well: during this period Hungary had to completely rebuild its economy three times and also had to survive two global crises. As the consequence of these external shocks, Hungary could not achieve lasting, sustainable economic growth and experience convergence. History taught, that geopolitics can determine the fate of nations, hence forming alliances is essential to prosper. In recent years, Hungary has joined forces with the also rapidly developing countries of the Carpathian Basin, and this will contribute significantly to future convergence and at the same time improve the fate of our fellow Hungarians who live outside Hungary.

However global geopolitics and economic cycles do not explain all the differences in countries' economic developments. Good governance and sound economic policy are indispensable to climb the development ladder. The two decades of Hungarian economic development following the collapse of socialism was instructive. Excessive liberalization and reckless fiscal policy impeded permanent convergence and led to recurring crises. Fortunately, lessons have been learnt. After 2010 the government introduced several fiscal and structural reforms to stabilize the economy, enhance growth and improve competitiveness. The implementation of the reforms was frontloaded, as most of them were introduced or implemented between 2010 and 2013. As consequence, a period of economic convergence has started in 2013, and by 2019 Hungarian regained its position among the best-performing economies in the region. Furthermore, the economy retained its stability over the whole decade, which is an unprecedented achievement.

In this paper I cover the last hundred years of Hungary's economic history. The starting point is the tragic, externally imposed Trianon Peace Treaty, which disrupted Hungary both in economic and geopolitical terms. I will discuss the economic impact of the horrors of World War II, the oppression by communist state and the transition to market economy. I will argue that in addition to wars, decades of political repression and recurring global economic crises, also domestic economic policy mistakes hampered Hungary's convergence. Still, in some periods Hungary was able to attain partial convergence, but it was always halted by external shock or domestically induced imbalances. As the country financed its development mostly from mounting external indebtedness, Hungary's growth model was long characterized by a choice between growth and balance. In the absence of a modernizing economy and improving competitiveness, convergence opportunities often very quickly fell by the wayside as the winds of the world economy changed.

This paper relies strongly on analysis and the datasets compiled in the book titled $10 \times 10$ years in numbers - The economic history of Hungary for the last 100 years (MNB, 
Barnabás Virág: Economics 10x10 - Lessons from the Last Ten Decades...

2020), which covers the last ten decades separately based on as comprehensive data as possible. This paper is more focused on policy dilemmas and emphasizes the importance of both external and internal factors in economic development. In the following first I will briefly discuss the main measures I use for economic progress and give an overview of the whole hundred years. Then I discuss three periods separately. The first period starts with the Trianon treaty and lasts until the start of the soviet repression. The second period covers the socialist era and the third the next three decades.

\section{KEY INDICATORS OF SUSTAINABLE DEVELOPMENT,}

\section{A BRIEF ASSESSMENT OF 1 OO YEARS}

Our key indicator of economic progress is the relative development of Hungary compared to Austria. However, focusing on this measure exclusively can be misleading from time to time. Purchasing power parity, a statistical measure essential for calculating relative development, is extremely hard to measure reliably even today, and going back in time increases the uncertainty of statistics tremendously. Hence relying on more indicators may be a better option. An alternative indicator of relative economic progress is growth rate differential. Although its measurement error can be high especially in the first half of the sample, it may provide valuable additional information on development. Even if these measures indicate convergence, one has to keep in mind, that high growth can be maintained for many years paying the price of growing economic imbalances. However, these periods tend to be followed by severe recessions, hence measures of imbalances are needed to check whether economic progress is real or fake. Finally, economic growth is of value for the society only if the benefits of growth are widespread, so the indicator set of economic progress should involve some direct measures of standard of living as well.

Keeping these caveats in mind, let's turn to the 100 years long time series of growth rate and relative development index of Hungary. One can observe that relative development fluctuated in a wide range, but there is no sign of a positive convergence trend in the whole sample. Big global downturns tended to hit the Hungarian economy severely, causing a drop in relative development. Growth rate differential shows that the Hungarian growth rate rarely exceeded the Austrian one. The economic harms caused by communist regime also quite striking. The almost half century of socialism did not provide any period of clear convergence and ended with the collapse of the economy. After the fall of the socialist system and a longer than expected transition period the economy started to converge. However, we are still within the historical band of fluctuation so further improvement of competitiveness is of paramount importance to maintain the convergence process.

From time to time over the past 100 years, the Hungarian economy was temporarily able to achieve rapid economic growth, but prior to 2010 this was always accompanied by the deterioration in external and internal balances. Sound macrofinancial balances are often neglected as factors of convergence, but on the long run their importance is as high as the importance of economic growth. Economic history makes it 
Civic Review · Vol. 16, Special Issue, 2020

Figure 1: Periods of growth and convergence in Hungary compared to Austria

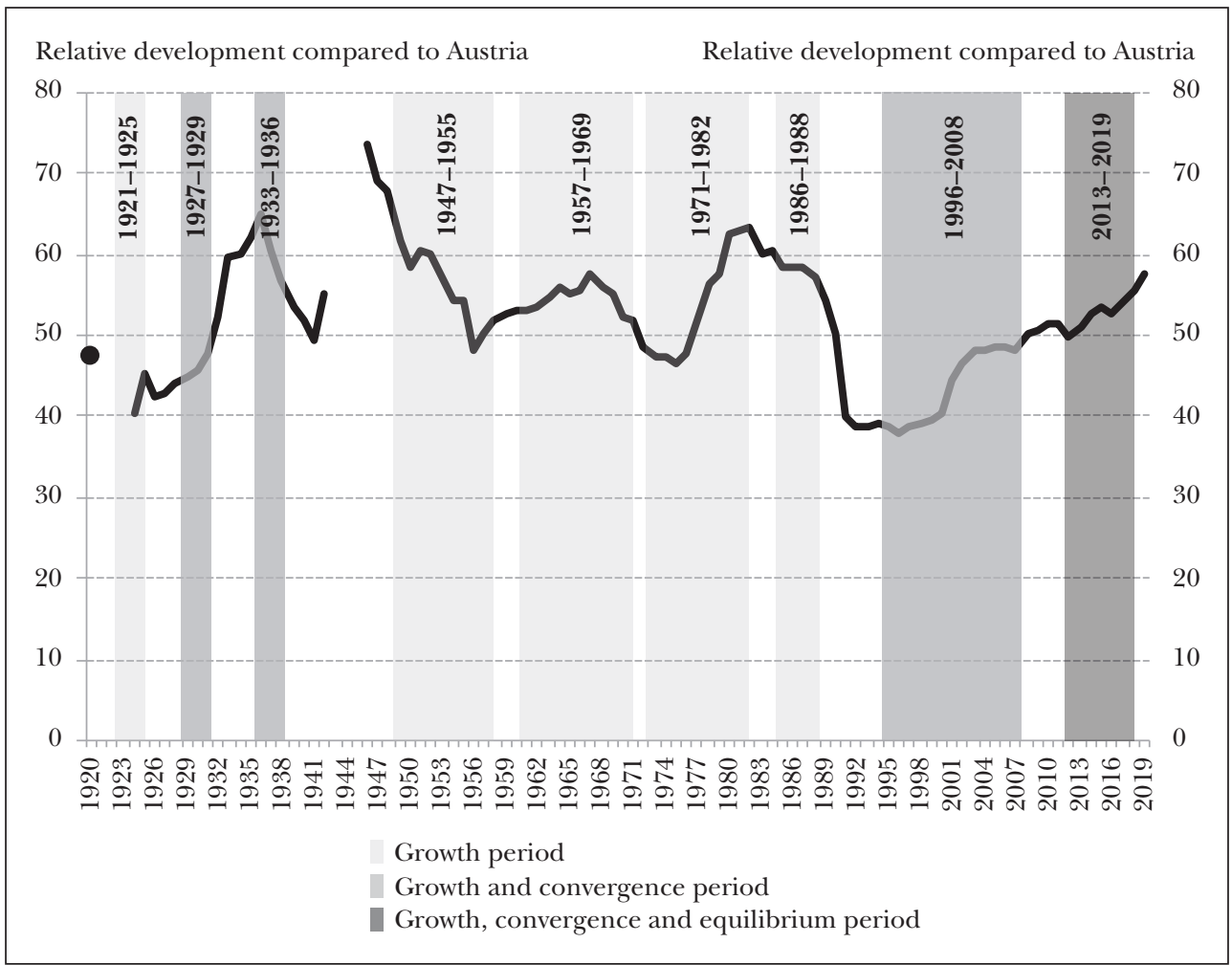

Note: On the basis of the data of Maddison until 1990, Ameco from 1991 and Eurostat from 1995.

Source: Maddison, Ameco, Eurostat and MNB

obvious that persistent economic growth is only feasible if equilibrium is maintained, as imbalance often leads to crises that slow down growth for years or even a whole decade. One of the main obstacles to developing countries' convergence is that they are hit by more frequent and stronger crises than developed countries. These crises may stem from serious internal problems, or if there is imbalance, a country may also be hit harder by external shocks.

There are various examples of economic imbalances in Hungarian economic history, for example in the 1980s and the 2000s imbalances occurred in the form of accumulating external indebtedness. Indebtedness first led to stagnation, then amplified the impact of strong external shocks (disintegration of the socialist bloc and the global financial crisis, respectively), and caused severe recessions.

In addition to growth and equilibrium, the third factor of economic convergence is the standard of living and welfare. Economic growth benefits societies only if the growth is inclusive. Research on wealth and income distribution in recent decades showed that economic growth does not necessarily go hand in hand with increasing prosperity. Unregulated liberal market economies tend to create excessive inequali- 
Figure 2: Government debt and inflation

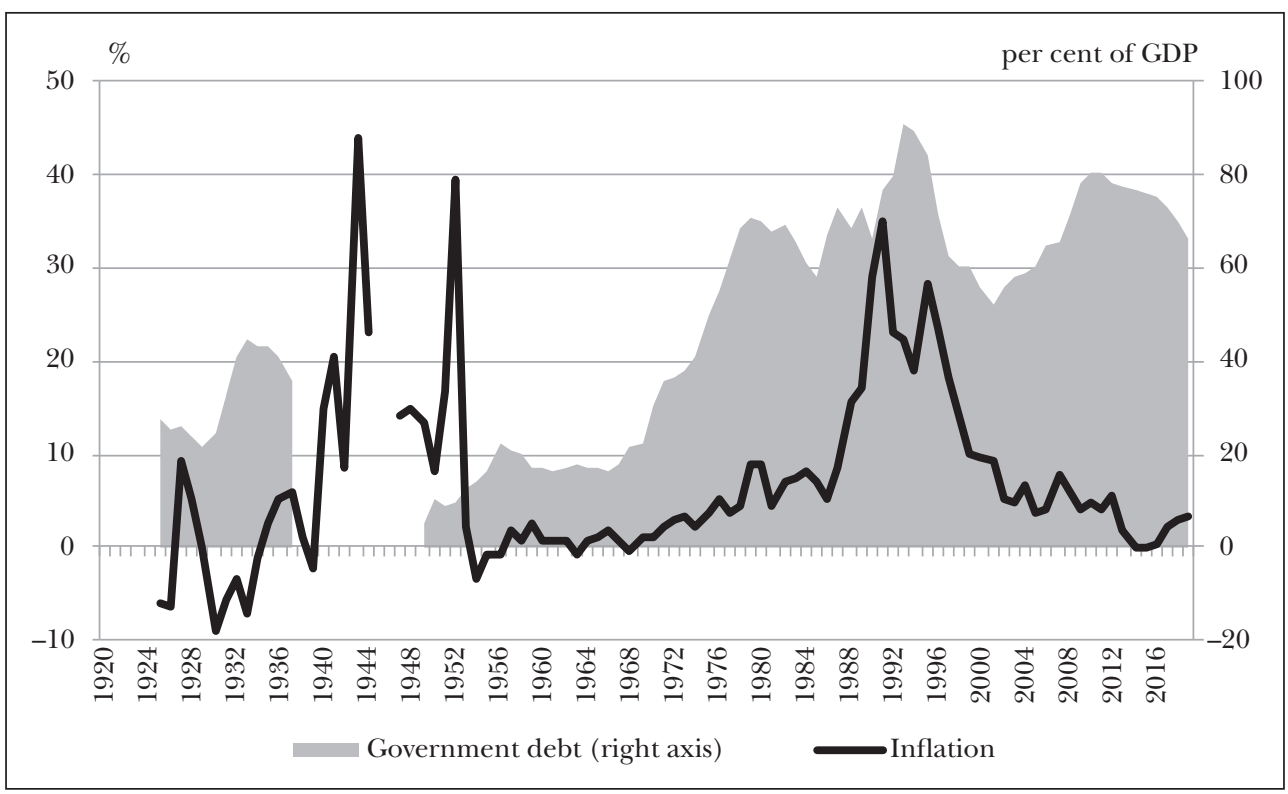

Source: HCSO and MNB

ties, increase social conflicts, which on the long run undermine the drivers of future economic growth through limited social mobility and negative effects on human capital accumulation. These problems are calling for state intervention. However, too much state intervention may backfire as well. In Hungary one of the inherent failures of the socialist system was that while it aimed for excessive equality, it did not reward individual performance and innovation. Economic history suggests that those countries were successful where the abilities and strengths of the state and the market were harmonised. The balance between the state and the market contributes to the rise of a broad middle class, which increases cohesion, facilitates the development of human capital and contributes to rising labour productivity.

Standard of living is influenced by numerous factors, including many non-economic ones. At the beginning of the 100 years timespan Trianon caused an enormous trauma not only at a national but also family level. 63 per cent of the population found themselves outside Hungary, and many families were torn apart decreasing standard of living in an unquantifiable manner. However, during the last 100 years in respect of living standards Hungary made big progress. The improvement was not continuous, for example life expectancy at birth rose to 69 years by 1966, when it stopped, and only exceeded that level at the turn of the millennium.

To have a full grasp of economic development, in the next three chapters I will discuss the economic progress of Hungary alongside the aforementioned three dimensions: economic growth, macroeconomic imbalances and standard of living. As I will show most of the time Hungary didn't have the opportunity to converge to the 
Civic Review · Vol. 16, Special Issue, 2020

Figure 3: Life expectancy at birth and the number of people living in one room

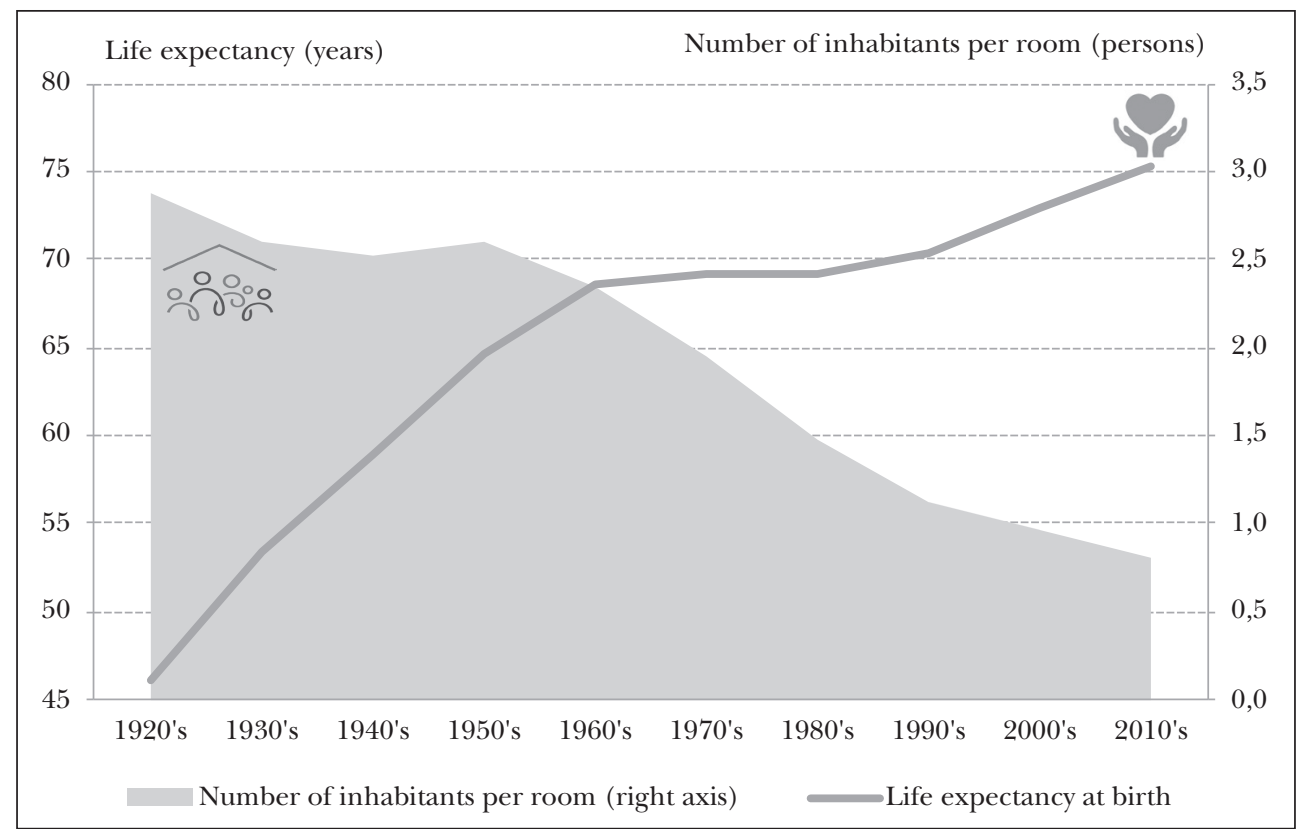

Source: HCSO and MNB

more developed European economies due to external factors and domestic failures. However, in the last decade the appropriate economic policy ensured both economic growth and macrofinancial balances, thus a convergence period emerged and there is new hope for continuous economic progress.

\section{From the Trianon TREATy TO THE WORLD WAR II}

The last hundred years started with a historic trauma, the Trianon peace treaty, Hungary lost 71 per cent of its territory and more than 63 per cent of its population. If was a disaster for the economy, which had already suffered huge losses during World War I. The new borders completely destroyed the production chains. While a significant portion of the processing capacities remained within the new borders of Hungary, the extraction of mineral resources and more than half of the arable land went to the detached parts. In some industries the new borders caused severe overcapacities. In railway machinery manufacturing, production had previously met the overall need for machinery throughout the country's rail network, but after the treaty barely 40 per cent of the rail network was within the new national borders. The previously worldfamous Hungarian milling industry lost most of its raw material base. Before the war, Budapest was the world's second largest mill city. In the early 1920s, however, grain production in the new territory of the country was not even enough to tie up the capacity of the mills in Budapest alone (Berend and Ránki, 1972). 


\section{Barnabás Virág: Economics 10x10 - Lessons from the Last Ten Decades...}

The dissolution of the Austro-Hungarian Monarchy altered many previously internal trade connections to external. Previously, the majority of Hungarian production was sold in the Monarchy's protected internal market of 50 million inhabitants, and most of the domestic use came from the Monarchy as well. Because of the new borders foreign trade became more important, both to meet industrial demand for raw materials and to satisfy households' consumption needs. In order to regulate Hungarian foreign trade a new tariff regime was established. The customs policy primarily protected the interests of Hungarian industry, tariffs of 30 per cent were imposed on processed products and duty rates on light industry were close to 50 per cent.

The financial sector also had to be restructured completely. In 1924, the Magyar Nemzeti Bank was founded. To ensure the foreign exchange demand of imported goods fixed foreign exchange management was introduced, exporters were obliged to convert their foreign exchange earnings into domestic currency and this was used to cover the foreign exchange demand of authorised imports (Szakács, 2000). Fixed foreign exchange management was in force until up to the end of 1925 (and was subsequently reintroduced in 1932).

Figure 4: Impact of the Treaty of Trianon on the main macroeconomic indicators and structure of the Hungarian economy

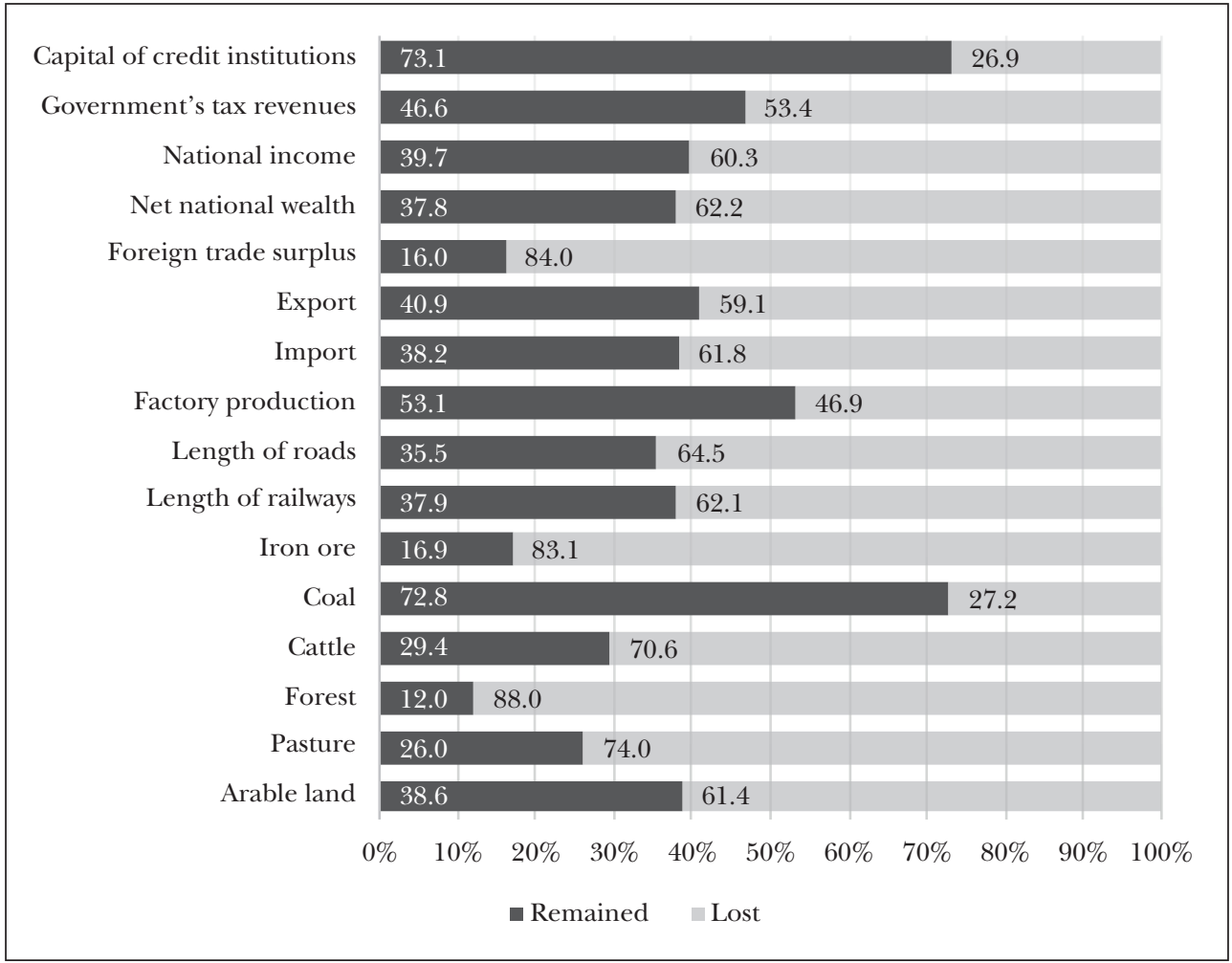

Source: Magyar Statisztikai Szemle (1938) 
Despite the enormous challenges the economy recovered from the shock of the war and the Trianon treaty fast, and production already reached the pre-war level by 1927 (in the territory of post-Trianon Hungary). The Great Depression of 1929-1933, strongly affected the Hungarian economy via recessions in its export markets, but then the recovery resumed. Several Hungarian companies reached European levels in their production, which - in a country poor in raw materials - operated in high-valueadded sectors. Examples of these are Tungsram and Orion in the manufacturing of electronic equipment sector, or the Weiss Manfréd Works and the Ganz factories in machine construction (Romsics, 2017).

Since the beginning of the 1920s trade relations of Hungary changed substantially. At the end of the 1920s Austria was still Hungary's most important foreign market (accounting for 29 per cent of exports), however in the 1930s Germany became the largest export market and Italy also gained in importance. On the import side, the change in product composition clearly reflected the increasing competitiveness of the domestic industry. The import structure shifted radically from finished industrial products to raw materials. 1920, only 22 per cent of imports were raw materials and semi-finished products, while nearly 78 per cent were finished products. In $1930 \mathrm{im}-$ ports of raw materials and semi-finished products rose to 74 per cent, while the ratio of finished products fell to 26 per cent (Szakács, 2000).

The World War II put a stop to economic progress. Wartime economy was introduced, production inputs were reallocated to industries producing for the army. When fighting took place in the territory of Hungary in 1944-1945, production declined to half the level reached in 1938-1939. The fall was especially high in agriculture and manufacturing industry. During the war, some 40 per cent of the national wealth, equivalent to around four years of GDP was lost, and war reparations amounted to another 2.5 years of GDP (Bokor, 1955).

Between the two world wars it was extremely difficult to reach and maintain sound macrofinancial balances given the substantial shocks the economy was hit by. However as foreign financing wasn't available from time to time, the government and the private sector had to accommodate fast. At the beginning of 1924, Hungary managed to obtain a significant amount of loans from the League of Nations, albeit under quite unfavourable financial conditions. The conditions for lending also included the need to achieve budgetary balance within two years. To improve the budgetary situation, direct taxes, income and property taxes, excise taxes and customs duties were significantly increased. The increase of tax revenues was supported also by the economic growth. The fiscal balance was already restored in the 1924-1925 fiscal year and maintained in the second half of the 1920s. During the depression of 1929-1933 the budget deficit and government debt started to increase due to declining tax revenues and increasing export subsidies, but government managed to return to balanced budget in the second half of the 1930s (Matolcsy and Varga, 1938).

The availability of foreign financing strongly influenced the current account deficit. To restore production capacities after World War I investment had to be boosted and its financing need was enormous. However foreign financing became available only 
Barnabás Virág: Economics 10x10 - Lessons from the Last Ten Decades...

in the second half of the 20s. Thereafter the import demand of the growing economy led to large current account deficit, which was increased further by the high interest payments on international loans. In the Great Depression the international financial system collapsed and foreign financing for Hungary was again not available. The current account became balanced after a huge adjustment of trade flows (Kaposi, 2010).

Despite the external shocks fiscal policy managed to find the right balance to ensure the growth of the economy. However, this fragile balance was destroyed by World War II. Government debt increased to about 50 per cent of GDP in Hungary by 1943. External borrowing was not an option, so the Magyar Nemzeti Bank printed money to cover the general government's expenditures, which led to high inflation. The purchasing power of the currency collapsed after the war, and Hungary suffered one of the fastest inflation rates in global history (Botos, 2016). Macrofinancial stability was destroyed completely.

Despite the swings of economic growth in the two decades following the 1920 trauma standard of living increased substantially, especially in the urban area. This was less due to economic growth. In the industrial sector, because of the Great Depression, real income did not reach the pre-war level even in the latter half of the 1930s. However living conditions improved because of the many achievements of modern social policy implemented in the second half of the 1920s. From then on, 80-90 per cent of the urban working class received sickness and accident insurance, and in 1928, compulsory old-age, disability, widowhood and orphanage insurance for urban workers was introduced.

One of the outstanding achievements of the 1920s was the reform of Hungarian education, linked to Kunó Klebelsberg. The most important achievement of public education was the eradication of illiteracy. In 1940, 92 per cent of the population over the age of 6 could read and write, which was an outstanding result compared to the surrounding Eastern European countries. The standard of contemporary secondary education was recognised as high, and at the same time, the number of secondary school graduates grew (Gunst, 1996). In 1938, nearly 6 per cent of the adult population had completed secondary school. This ratio was only slightly lower than in Germany and slightly higher than in France.

Public health reform began also in the 1920s. It started from a relatively advantageous position as after the new borders were set in 1920, about five sixths of the doctors settled down within the new borders of Hungary. Between the two World Wars, the number of doctors and hospital beds increased further. Due to better health care the number of deaths caused by infectious diseases declined substantially, and life expectancy at birth increased from 42 years to more than 55 years (HCSO, 1996).

\section{ECONOMIC DEVELOPMENT DURING THE SOVIET ERA}

After World War II a socialist economic model was introduced in Hungary based on state ownership and complete state control of production and prices. The new international economic cooperation was set by the Soviet Union, and that totally changed 
Civic Review · Vol. 16, Special Issue, 2020

the role of Hungary in the global economy. The new economic model led to the end of the agricultural and light industry traditions and to the forced development of heavy industry, which did not have a raw material base.

The soviet economic model suffered from severe shortcomings. The model discouraged individual performance and preferred equality to efficiency excessively, hence it was unable to produce long-lasting economic results. Economic growth was hindered by the absence of market coordination, the lack of incentives to innovate and to put efforts into boosting productivity. Companies received hardly any profits from their innovations, while their losses were covered by the state (soft budget constraint). The rigidity of the system led very low efficiency, but because of state control the consequences could be masked temporally. Inflation was prevented by officially fixed prices, while unemployment was countered by inefficient employment, i.e. 'unemployment within the gates'.

The inefficiency of the socialist economic model was so apparent, that even the socialist governments introduced cautious reforms. From 1968, the command economy system was slightly eased with the introduction of the New Economic Mechanism. Part of the after-tax profit could be managed by the companies, and companies could decide on some investment projects, although major investments were decided definitely upon by the state. Another important measure was the creation of a limited market for consumer goods and means of production. The prices of about 30 per cent of the products became non-regulated, although the price of basic foodstuffs, raw materials and services continued to be set by the state (MNB, 2016). The reform had some early success. However, after some negative feedback from the Soviet Union the new measures were withdrawn in the mid-1970s. Over the course of the 1980s the state implemented some new reforms related to the tax system, private ownership and the banking system. However, these reforms lacked an integrated concept and were supported by political leaders half-heartedly. Finally, under economic and social pressures and due to its inability to adjust, the socialist systems collapsed.

Macrofinancial balances in the socialist were strongly influenced by the inability of the economy to adjust and socialist governments' priority to continuously increase households' income. The reconstruction of the economy and the enormous investment into the heavy industry created a substantial financing need and eventually put a strain on maintaining macrofinancial balances in the soviet era. However, after the socialist economic system was introduced macrofinancial imbalances became harder to quantify. In the system based on nearly complete state ownership, the general government deficit and government debt became concepts that were hard to interpret, because it was not easy to draw the line between the general government and the system of state-owned companies. Relative prices were distorted to support heavy industry to the detriment of light industry, services and agriculture, which created new forms of imbalances not detected by traditional statistical measures (like shortages).

However, the socialist governments' priority to continuously increase households' income to avoid social tensions was harder and harder to reconcile with sound macrofinancial balances. This became apparent in the 1970 s, due to the increasingly un- 


\section{Barnabás Virág: Economics 10x10 - Lessons from the Last Ten Decades...}

favourable change in the terms of trade (primarily due to sudden oil price increases). Although the oil price shock affected the socialist countries with some delay, as the price of the Soviet oil exports only started to increase from 1976, the socialist economies were unable to adjust. Due to these unfavourable changes in trade prices and to the uncompetitive exports, from 1974 significant deficits emerged in the trade balance and also in the current account (HCSO, 1989). Due to the strong interdependence between the economy and the state, the above was reflected in the increase in government debt as well, which rose from 30 per cent of GDP to 71 per cent during the decade. The debt was almost entirely external, and more than half of it was denominated in US dollars and German marks (in fact, some of it was lent on to other socialist countries). Hungary's accession to the IMF in 1982 was primarily motivated by the interest in remaining able to borrow from Western investors. In the 1980s, the amount of loans outstanding was increased not only by real economic developments, but also by poor financial decisions (the appreciation of the outstanding loans and their high interest rates).

Accumulated macrofinancial imbalances contributed to the collapse of the socialist system substantially. The simultaneous, and permanently high deficit of the current account and the general government budget could not be maintained financially. Furthermore, due to the unsustainably increasing debt the artificially low level of consumer (especially energy and gasoline) prices had to be abandoned as well, which led to increasing inflation. To restore macrofinancial balances a substantial adjustment was needed, but due to its inevitable social consequences it could not be executed politically within the socialist regime (Honvári, 2013).

Steady increase of living standard while avoiding significant inequalities within society was the main promise of the socialist system. However, it became apparent that state control and maintaining excessive equality decreased efficiency in such an extent, that it decreased the standard of living actually. Furthermore, especially at the first half of the soviet era state control extended far beyond economic policy (like the abortion laws of the Ratko era), which decreased the quality of life substantially. The retaliation after the revolution in 1956 led to the emigration of 200000 people and had many detrimental consequences on living standards in various ways (HCSO, 1996). Putting this aside in some aspects standard of living improved gradually. From the 1960s, households were already able to save an increasing portion of their disposable income, which was initially reflected in savings for housing and later in the rise in financial wealth. Urbanization was also substantial, although government could not address housing problem adequately. In the 1960s and 1970s around 60,000-90,000 flats were built annually, but two thirds of these were built privately. The quality of flats remained low, in 1969 nearly two thirds of the population still lived in homes without modern utilities. The rise in life expectancy also stopped at 69 by 1966, and only exceeded that level at the turn of the millennium. Starting from the end of the 1970s, partly due to the surge in oil prices and partly as a result demographic factors, the standard of living stopped rising. Real earnings started to decrease, which could only be offset by increasing the benefits provided by the state. However, the gap between 
Civic Review · Vol. 16, Special Issue, 2020

the living standard of Western Europe and the soviet bloc became increasingly apparent even before the fall of the socialist system.

\section{RETURN TO MARKET EGONOMY}

The three decades after the collapse of the socialist bloc can be divided into two subperiods. The first two decades can be taken as a prolonged transition period, which was made by government policy mistakes even longer. However, despite the failures Hungary reintegrated to the European economy and in 2004 joined the European Union stabilizing its geopolitical position. In the third decade the government and the central bank managed to implement a new successful convergence strategy, and economy started to grow rapidly.

\section{From transition crisis to the Great Recession}

After the collapse of the socialist bloc, in 1990, Hungary held free, democratic elections for the first time in its history and Prime Minister József Antall formed a government. The public expectations were high, the trust in democracy and market economy was strong, that they will deliver rapid development and quick convergence to the Western countries. However, the transition proved to be more prolonged than expected. Economic policy applied a rapid transition to a market economy, the so-called shock therapy. Trade was liberalized, tariffs and export subsidies were decreased. The environment of companies changed rapidly, giving too little time for economic agents to adjust. Hungary lost its East European trading partners, while it was not competitive vis-à-vis the Western economies. The transition led to deep economic crisis and 1 million jobs disappeared. The decline of the household income was somewhat mitigated by fiscal transfers to households for a while, but this led to ballooning fiscal deficit. In the mid-1990s the government implemented measures to restore macrofinancial balances, including fiscal tightening, devaluation of the exchange rate, higher import duties. These tightening measures lowered economic growth further.

Fortunately, the efforts to reintroduce the market economy started to bear fruits. As Hungarian labour was skilled and wages were low, foreign direct investment flowed into the economy. Companies became more integrated into the European economy and export started to grow rapidly. By the late 1990s, the share of the European Union became dominant in Hungary's foreign trade. Hungary's geopolitical position was also strengthened by the NATO accession in 1999 and the European Union in 2004, which ensured the stability needed for long term economic progress.

Foreign companies settling in Hungary played an important role in economic growth and modernisation, but at the same time they contributed to the development of a dual economic structure. Foreign-owned large corporations were competitive with access to the whole world's export markets, whereas the productivity and competitiveness of Hungarian-owned small enterprises lagged behind. The huge productivity gap became permanent, which indicated structural weaknesses of the economy. 


\section{Barnabás Virág: Economics 10x10 - Lessons from the Last Ten Decades...}

The first years of the new millennium saw Hungary as the economic front-runner of the CEE region, but by the mid-2000s the state and households could only maintain economic growth from external funds, paying the price in the form of simultaneously high budget and current account deficits and mounting external debt. All of this led to the stoppage of economic growth already after 2006. In addition to low employment and subdued investment activity, also high indebtedness in foreign currency became a serious structural problem. As a result of the policy mistakes of the $2000 \mathrm{~s}$, the global financial crisis of 2008-2009 found Hungary in a very vulnerable position. Hungary, which had been a front-runner in the region, became one of the weakest countries of the region.

During the 20 years following the regime change the most important reason for the weak relative regional performance was the inability of economic policy to reach and maintain sound macrofinancial balances. Equilibrium and economic growth could only be achieved to the detriment of one another. During the first years of the transition, the economic recession reduced imports, resulting in a balanced current account, but the budget deficit grew further due to the fall in tax revenues. In the CEE region, Hungary switched to a market economy with the highest level of government debt, and the crisis of economic transition increased the debt ratio from 66 per cent in 1990 to 90 per cent in 1993 (P. Kiss and Szapáry, 2000). Following that, the economy showed signs of recovery as GDP expanded, while the debt ratio declined. At the same time, however, the current account deteriorated. To restore balances the government devaluated the forint and increased administered prices in the mid-1990s (Szapáry and Jakab, 1998). Inflation remained high for years (declining to below 20 per cent only in the late 1990s). Around the millennium, economic policy simultaneously achieved an improvement in financial equilibrium and accelerated economic growth, but this period ended with the drastic increase in the budget deficit from 2002. Serious twin deficit evolved again by the mid-2000s; government debt and the foreign debt of the whole economy grew simultaneously.

Although the first 20 years following 1990 saw an overall improvement in the standard of living, there were strong fluctuations in parallel to economic cycles, and widespread development only evolved in the 2010s (Matolcsy, 2015). The political transformation caused strong social shock instead of the expected freedom and welfare. As a result of rapid market liberalisation, deregulation and privatisation, a large portion of the domestic industry and enterprises disappeared, and around 1 million people lost their jobs, many of them permanently, while real wages declined considerably. Consumption started to increase again in 1993 and real income in 1994, but then government measures to restore balances restrained further improvement (Matolcsy, 1996). Starting from 1995, real wages declined by 16 per cent in two years, and per capita consumption fell by nearly one tenth. Following that, households' income and consumption rose steadily until 2006, but after 2002 this was accompanied by increasing government debt and household loans. The fiscal austerity package in 2006 reduced the standard of living again, even prior to the outbreak of the financial crisis. Following that, due to the financial and its mismanagement the number of un- 
Figure 5: Current account balance and government balance as a proportion of GDP in Hungary

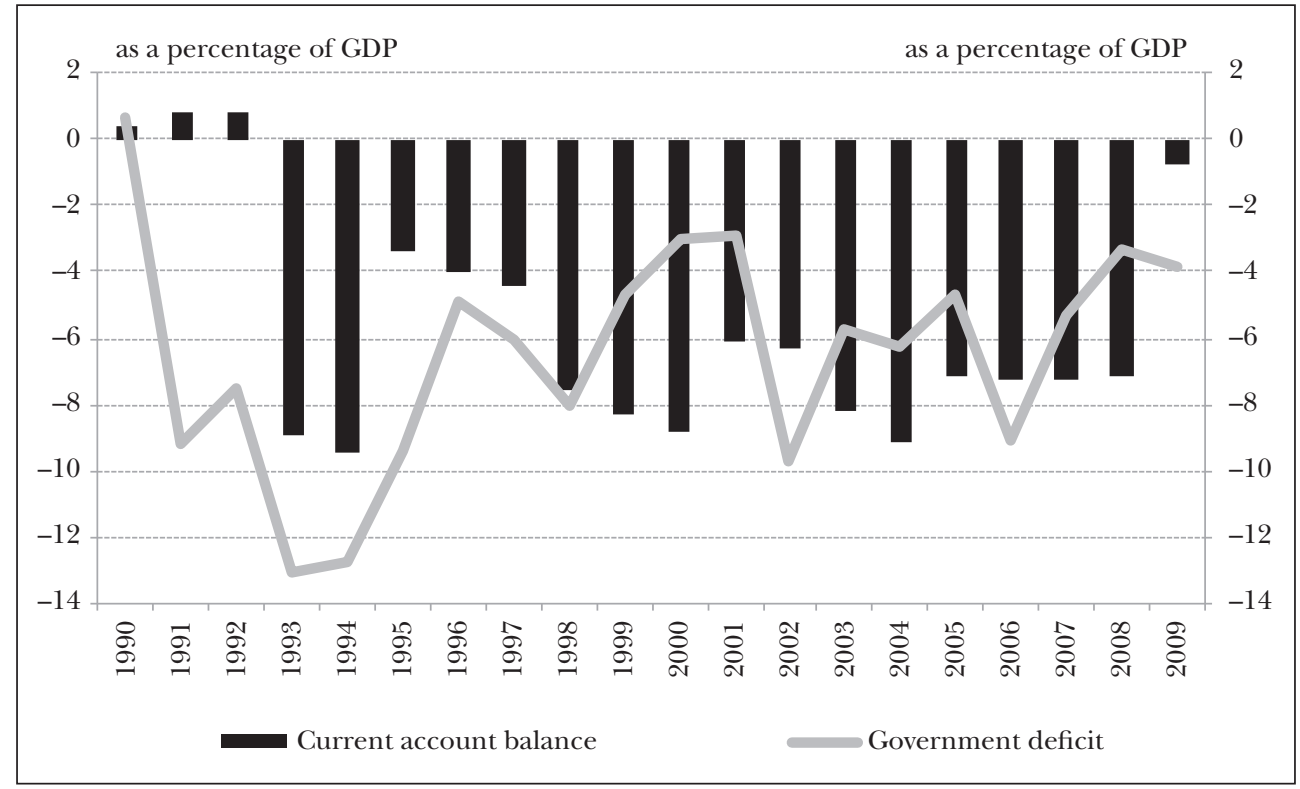

Note: Fiscal deficit data show the current methodology. Contemporaneous data indicated smaller deficit for 1990-1999.

Source: 1990-1999: P. Kiss and Szapáry, 2000; 2000-2009: MNB

employed grew by around 150,000, while the real earnings of employed declined. The rise in the instalment of households' previously accumulated foreign currency-denominated loans endangered housing of large number of foreign currency debtors.

The swings in economic development and households' income, the loss of job security and the growing unpredictability and uncertainty of everyday life had a detrimental impact on the fertility rate as well. Total fertility rate started to decrease already in 1980s, but its decline accelerated in the prolonged transition period. The fertility rate plunged to 1.3 and remained low creating a new, long-term challenge for Hungary (see Figure 6).

\section{Convergence with sound macrofinancial balances}

The new economic policy approach started in 2010 aimed at the simultaneous achievement of economic growth and equilibrium and regarded the increase of employment as a crucial factor. As a result of fiscal reforms after 2010 and monetary policy measures from 2013, Hungary embarked on the path of growth and convergence. Next to ensuring macrofinancial balances government took an active role to enhance competitiveness of the economy. Since 2010 many new measures have been launched and implemented, especially in the first half of the decade. 
Barnabás Virág: Economics 10x10 - Lessons from the Last Ten Decades...

Figure 6: Fertility rate (1970-2019)

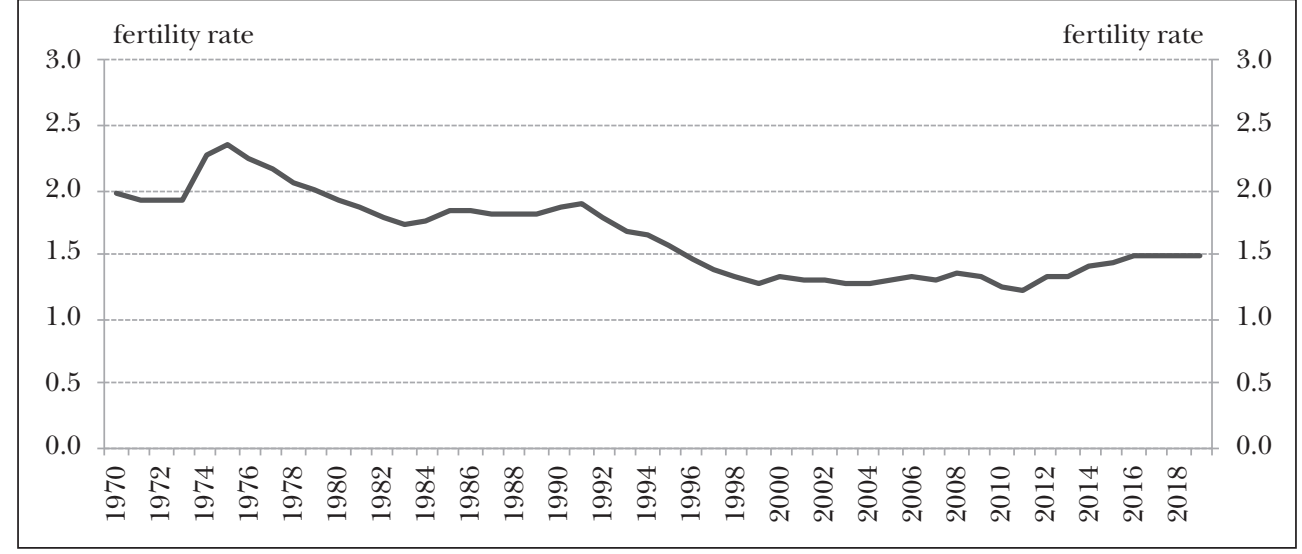

Source: HCSO

Figure 7: 50 reform measures since 2010

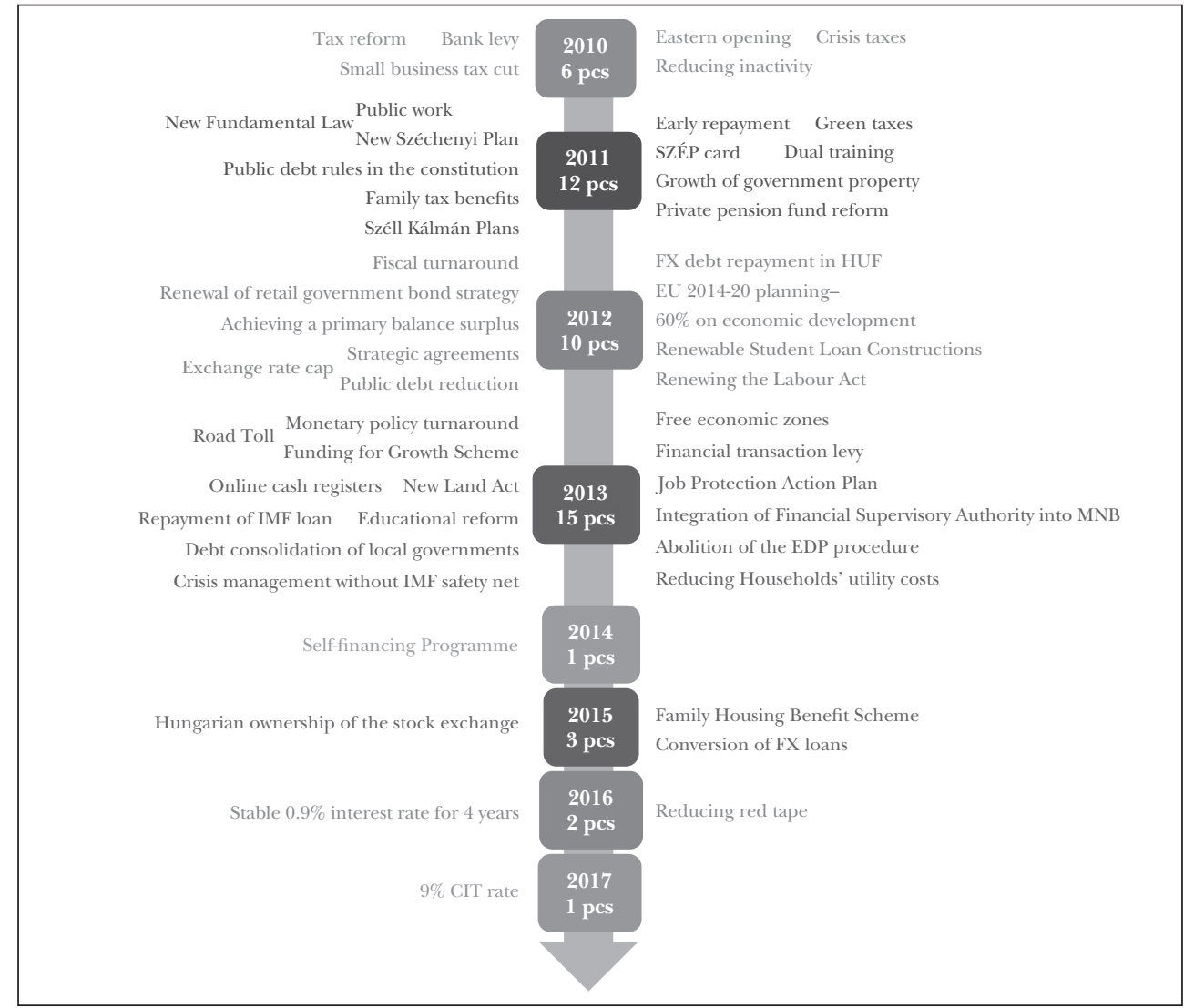

Source: Baksay et al., 2020 
Civic Review · Vol. 16, Special Issue, 2020

Due to the supportive public policy the average growth rate of the Hungarian economy was 3.8 per cent between 2013 and 2019. This was 2 percentage points higher than the average of the European Union and led to a quick convergence (Matolcsy and Palotai, 2018). By the end of the decade, the investment rate had become one of the highest in the European Union, projecting that the high growth period will continue. By the end of the decade, the level of Hungarian economic development exceeded 74 per cent of the level of the EU average and surpassed the levels of Poland and Slovakia.

The general government deficit and other indicators of macro-financial stability improved significantly after 2010. With the necessary adjustment of the economy, the current account already started to improve during the crisis, followed by rebalancing of the budget from 2012 as a result of new types of fiscal reforms focusing on both economic growth and equilibrium (Matolcsy and Palotai, 2016). Starting from 2013, there was a turnaround in monetary policy. Maintaining the priority of the inflation target the central bank reduced interest rates, encouraged lending in a sound structure, supported the transformation of households' foreign currency loans into forint-denominated loans and contributed to the financing of the economy. During the decade, both government debt and external debt declined steadily, with net external debt falling to around 10 per cent of GDP. The almost completely balanced state of the economy is further reflected by the low inflation, which has been close to the 3-per cent central bank target since 2017 (Hajnal and Várhegyi, 2019).

The government's choice to give absolute priority to raise employment was important for the inclusivity of economic growth and raising standards of living. In 2010, the proportion of working people within the population in Hungary was the lowest in the European Union, but in the next ten years employment expanded by some 800,000 people, and thus Hungary reached the EU average. The increase in employment was followed by the rapid increase of real wages in the second half of the decade, hence more and more people benefited from the economic growth. In the 2010s, Hungary experienced the largest decline in the proportion of social groups that face the risk of poverty and social exclusion. Furthermore, due to high growth and rapidly increasing financial wealth of households, inequality remained moderate in international comparison.

The new housing policy of the government aimed to raise standard of livings through ensuring affordable housing. The problem of housing was dated back to socialism and continued after the political transition. Both lack of housing supply and lack of affordable financing contributed to the insufficient number of new homes. In the 2010 s the government introduced new targeted subsidies to support housing, while the central bank strengthened consumer protection and launched new regulations to ensure the fairness and competitiveness of the mortgage lending market.

In the realm of raising living standards the support of families became the focus of public policy. Many new family-friendly programmes were introduced and cash 
Barnabás Virág: Economics 10x10 - Lessons from the Last Ten Decades...

benefits for families with children are among the highest in Europe. However, the demographic trends proved to be quite challenging to alter. Although fertility rate started to increase, it is still far away from the 2.1 level targeted by the government on the medium term.

\section{SUMMARY}

Hungary's attempts to reach the Western European level of economic development failed many times during the last hundred years. In this paper I investigated, why the convergence was hampered. By identifying the mistakes in the past, we may avoid repeating them in the future.

During the last hundred years the lack of convergence had external sources most of the time. The first half of the period, following the trauma of the Trianon treaty, and between the two world wars was used for successful reconstruction, but the outbreak of the Great Depression led to protectionism and the collapse of international finance, which put a stop on the progress of the Hungarian economy. After World War II the great powers agreed on their European sphere of influence and Hungary became member of the soviet bloc. Planned economy was implemented, what ruled out convergence for another four decades.

After the collapse of the soviet bloc market economy was introduced and Hungary reintegrated into the European economy, which provided a historical opportunity to converge. However, the transition period was more prolonged than expected because the adoption of new technologies, the reallocation of resources and implementing new regulations took time and economic agents had to adjust. Government policy mistakes made the situation even worse by letting macrofinancial imbalances to grow for the sake of short-term economic growth. Hungarian governments had to face from time to time that permanent convergence is not feasible without sound macrofinancial balances.

Finally, during the last decade Hungary started to use its historic opportunity well. Government recognized that policies should enhance competitiveness, safeguard macrofinancial stability and ensure the inclusiveness of economic growth simultaneously. To new approach proved to be successful, and after 2013 the economy started to converge rapidly. The Hungarian economy is in better shape than ever and government have enough room for manoeuvre even during global shocks to maintain economic progress. 
Civic Review · Vol. 16, Special Issue, 2020

\section{REFERENGES}

Acemoglu, D. and Robinson, J. A. (2013): Why Nations Fail. The Origins of Power, Prosperity, and Poverty. Crown Publishers, New York.

Baksay, G.; Nagy, Á; Palotai, D. and Szalai, Á. (2020): A reformok és a felzárkózás évtizede - 50 reformlépés az egyensúlyi felzárkózás megteremtéséhez [A decade of reforms and catching-up - 50 reform steps to achieve equilibrium catching-up]. Magyar Nemzeti Bank, Budapest.

Berend, T. I. and Ránki, Gy. (1972): A magyar gazdaság száz éve [100 years of Hungarian economy]. Közgazdasági és Jogi Könyvkiadó, Budapest.

Bokor, B. (1955): Magyarország háborús károsodása a II. világháborúban [The war damage of Hungary in World War II]. Statisztikai Szemle, No. 2, 183-189.

Botos, J. (2016): A pengố megsemmisülése, a forint születése, 1938-1946 [The destruction of the pengô, the birth of the forint, 1938-1946]. Múltunk, Vol. 61, No. 1, 160-206.

Gunst, P. (1996): Magyarország gazdaságtörténete (1914-1989) [Economic history of Hungary (1914-1989)]. Nemzeti Tankönyvkiadó, Budapest.

Hajnal, M. and Várhegyi, J. (2019): Három a magyar igazság - fontos mérföldkôhöz ért a hazai infláció ["Three is the Hungarian justice" - Domestic inflation has reached an important milestone]. Magyar Nemzeti Bank, Budapest.

HCSO (1989): Népgazdasági mérlegek, 1949-1987 [National economic balances, 1949-1987]. Hungarian Central Statistical Office, Budapest.

HCSO (1996): Magyarország népessége és gazdasága: múlt és jelen [The population and economy of Hungary: past and present]. Hungarian Central Statistical Office, Budapest.

Honvári, J. (2013): XX. századi magyar gazdaságtörténet [Economic history of Hungary in the 20th century]. Universitas-Gyôr Nonprofit Kft., Győr.

Kaposi, Z. (2010): Magyarország gazdaságtörténete 1700-2000 [Economic history of Hungary 1700-2000]. Dialog Campus Kiadó, Budapest-Pécs.

Matolcsy, Gy. (1996): Gazdasági és társadalmi sokkterápiák 1990 és 1995 között Magyarországon [Economic and social shock therapies in Hungary in 1990-1995]. Társadalmi Szemle, Vol. 51, No. 5, 3-14.

Matolcsy, Gy. (2015): Egyensúly és nözekedés. Konszolidáció és stabilizáció Magyarországon, 2010-2014 [Balance and growth. Consolidation and stabilisation in Hungary, 2010-2014]. Kairosz Kiadó, Budapest.

Matolcsy, Gy. and Palotai, D. (2016): A fiskális és a monetáris politika kölcsönhatása Magyarországon az elmúlt másfél évtizedben ([The interaction between fiscal and monetary policy in Hungary over the past decade and a half]. Hitelintézeti Szemle, Vol. 15, No. 2, 5-32.

Matolcsy, Gy. and Palotai, D. (2018): A magyar modell: A válságkezelés magyar receptje a mediterrán út tükrében [The Hungarian model: Hungarian crisis management in view of the Mediterranean way]. Hitelintézeti Szemle, Vol. 17, No. 2, 5-42, http://www.hitelintezetiszemle.hu/letoltes/hsz-17-2-t1-matolcsypalotai.pdf.

Matolcsy, M. and Varga, I. (1938): The National Income of Hungary. P.S. King and Son Ltd., London.

MNB (2016): A forint 70 éve: Út a hiperinflációtól az árak stabilitásáig [70 years of the forint: Road from hyperinflation to price stability]. Magyar Nemzeti Bank, Budapest.

MNB (2020): Trianon 100 - Tizszer tíz év számokban [Trianon 100. 10 x 10 Years in numbers - The economic history of Hungary for the last 100 years]. Magyar Nemzeti Bank, Budapest.

P. Kiss, G. and Szapáry, Gy. (2000): Fiscal Adjustment in the Transition Process: Hungary, 1990-1999. PostSoviet Geography and Economics, Vol. 41, No. 4, https://doi.org/10.1080/10889388.2000.10641140.

Romsics, I. (2017): A Horthy-korszak [The Horthy era]. Helikon, Budapest.

Smith, A. (1959): A nemzetek gazdagsága (An Inquiry into the Nature and Causes of the Wealth of Nations), Közgazdasági és Jogi Könyvkiadó, Budapest.

Szakács, S. (2000): Gazdaságtörténet II. [Economic history II]. Számalk Kiadó, Budapest.

Szapáry, Gy. and Jakab, M. Z. (1998): A csúszó leértékelés tapasztalatai Magyarországon. [Experiences with crawling-peg devaluation in Hungary]. Közgazdasági Szemle, Vol. 45, No. 10, 877-905. 